\title{
Corporate Communication Strategy and Sustainable Community Relations of Indorama Eleme Petrochemical Limited
}

\author{
Ihunwo, Owhonda Justice ${ }^{1}$, Richard N. Amadi, Ph.D ${ }^{2}$, Dike, Harcourt Whyte, Ph.D ${ }^{3}$ \\ ${ }^{I}$ Postgraduate student, Department of Mass Communication, Faculty of Social Sciences, Rivers State University, Port Harcourt, \\ Nigeria \\ ${ }^{2}$ Associate Professor, Department of Mass Communication, Faculty of Social Sciences, Rivers State University, Port Harcourt, \\ Nigeria \\ ${ }^{3}$ Senior Lecturer, Department of Mass Communication, Faculty of Social Sciences, Rivers State University, Port Harcourt,
} Nigeria

\begin{abstract}
This study examined corporate communication strategy and sustainable community relations of Indorama Eleme Petrochemical Limited. To achieve this, four objectives were set with equivalent four research questions. Stakeholders' theory and corporate community theory guided the study. The population of this study is 74,240 which is the sum of the respective populations of the six host communities of Indorama Elem Petrochemical Limited with survey as the research design. The researcher employed mixed method using questionnaire and interview as data gathering instruments. For the quantitative data, a sample of 382 was arrived at using Krejcie and Morgan sample determinant table and for the qualitative data; a sample size of 9 was used comprising 3 staff of corporate communication department of Indorama Eleme Petrochemical Limited and the 6 members of Project Advisory Committee (PAC). Respondents for the interview were purposively selected based on their knowledge of the subject matter and the fact that they can offer the needed answer to the study questions. The findings of the study show that corporate communication strategies of the company proved to be major contributory factor that enhanced sustainable community relations and ensured mutual understanding and harmony that currently exist between the company and host communities. The study therefore recommends that the Indorama Eleme Petrochemical Limited model of corporate communication strategies and sustainable community relations be adopted by companies operating not only in Rivers State but in Nigeria especially the $7.5 \%$ equity share to host communities. This is to ensure mutual understanding between companies and host communities.
\end{abstract}

Keywords: Corporate communication. Strategy. Community relations. Company

\section{INTRODUCTION}

$I^{2}$ ndorama Eleme petrochemical Limited is a world class organization with that produces fertilizer, preforms and industrial sack. The company carry-out its activities through operations, business models, quality control and assurance, occupational health, safety and environment management, security, finance, utilities, human resources management, port operations, pipeline management, information technology, corporate communications, community relations, among others. Central to these activities is the corporate communication which is saddled with the responsibility of ensuring not only industrial harmony but harmonious coordination of its activities through effective corporate communication. Communities being major stakeholders also remain indispensable if the organization must operate effectively and optimally. This is the reason why Comelissen (2011) citing Van Riel in his book on corporate communications, attests that corporate communication is basic to an organization survival in the advanced age and it is a critical part of the corporate work industry which in certain occasions is alluded to as a management work or an office inside a work environment committed to the execution of key corporate communication techniques both internally and externally. Comellison similarly recommends that corporate communications is 'an instrument of management through which all intentionally utilized types of interior and outside communications are blended as adequately and efficiently as could really be expected', with the general target of making 'a positive reason for relationships with bunches whereupon the company is reliant.'

Corporate communication departments are likewise answerable for the reputation of the partnership and its management, relationships with potential and existing investors, government issues, and furthermore showcasing, etc. Corporate Communication is the absolute of a company's endeavours to impart effectively and productively and the key activity taken by organizations to accomplish that objective depends in to a great extent on the character of the organization and its relationship with its stakeholders' likes providers, community, employees, and clients. So corporate communication turns into an essential gadget for the contemporary enterprise to expand an upper hand over its rivals as supervisors use it to lead, motivate, persuade, and advise employees and the general population also. Henceforth corporate communication can be viewed as the arrangement of exercises engaged with overseeing and organizing all inside and outer communications pointed toward making positive 
beginning stages with stakeholders on whom the company depends (Riel Van 2000).

Riel Van (2000) states further that in the event that organizations deliberately share what their identity is, their qualities, their insight and significantly, their errors, they will show up more noticeable, authentic, and accessible while drawing in with their crowds if future advertising and communication openings emerge. In the event that they veil their personalities, organizations hazard passing up open profiling openings, yet in addition undermining their believability as a pioneer or confided in source in their field and with their stakeholders.

Community relation is an articulation generally utilized by organizations all throughout the planet to portray their community contribution exercises and projects. Community connection is presently a genuine, vital part of business in light of the fact that serious business and social pressures are constraining a redefinition of the relationship among company and community. At the point when a company makes a pledge to the community part of its core business strategy, it's difficult draws in and hold top employees, however it additionally positions itself decidedly among clients and progressively advances its situation in the market. The essential part of business is to deliver labor and products for the general public and for the business to operate in a stable environment; the interdependence between business and host community becomes a necessity (Burke 1999)

Burke (1999) points out that to be successful in planning community practices and programs, a company needs to see how a community settles on choices and who gets included and why they engage in settling on or impacting community choices. It additionally should be delicate to the exceptional culture and upsides of the community wherein it works. Burke states further that building sustainable and progressing relationships in a community is a core strategy for turning into a neighbour of decision. The development of trust he says relies upon aware relationships.

To achieve this, a community relations policy must be adopted where corporate communication departments will have responsibility to create and keep up with constructive relationships with host networks through commitment and discourse, to fabricate trust and encourage authentic joint effort with nearby stakeholders. It additionally has the duty, along with government and different accomplices, to mitigate the impacts of organization activities and to exploit freedoms to improve sustainable socio-economic development. The company should likewise pay attention to and draw in with host networks in a culturally-fitting, straightforward and sexual orientation touchy way and to work proactively with networks to distinguish and oversee social dangers, impacts and commitments just as to assist with encouraging a steady, sound and safe climate in which they live and work. It should likewise address complaints in a fair, ideal and steady way and screen and ceaselessly try to further develop community relations performance to make an incentive for stakeholders.

\section{Statement of the Problem}

Eleme Local Government Area of Rivers State is host to many multi- national companies which Indorama Eleme PetroChemical happens to be one. In many parts of the state where multi-national companies operate; there is usually community agitations against companies by host communities and these crises sometimes lead to a shutdown of the company's operation. One would have expected Indorama Eleme Petrochemical Limited to have similar friction with host communities but it beats one's imagination why the company does not have such crisis over the years. Could it be that the corporate communication strategy of the organization is favourable to the host communities?

It may be possible that most organizations that do not incorporate community relations activities in their corporate communication strategies encounter challenges or difficulty in handling community issues when they arise. Could there be a potential danger that this neglect could suffocate the smooth operations of the company and invariably affects not only the profitability but the image or reputation of the organization.

Indorama Eleme Petro-Chemical Limited has been in existence for years and it appears that it has a cordial relationship with its host communities. Could this be attributed to the fact that there are corporate communication strategies the company adopts in ensuring sustainable community relations? It is in light of the above that this study was undertaken to unravelling the corporate communication strategies of Indorama Eleme Petro-Chemical Ltd and how it affects its host community relations.

\section{Objective of the Study}

The objective of the study therefore borders on the need to:

(1) find out the corporate communication strategies of Indorama Eleme Petro-Chemical Ltd.

(2) investigate the extent to which the corporate communication strategy of Indorama Eleme PetroChemical Ltd engenders sustainable community relations.

(3) ascertain whether host communities appreciates communication strategy of Indorama Eleme PetroChemical Ltd.

(4) identify challenges faced by Indorama Eleme PetroChemical Ltd in the application of corporate communication strategies of the organisation.

\section{LITERATURE REVIEW}

Communications practitioners must realize how to perceive, analyze and tackle communication-related management issues, consequently the requirement for the agreement that corporate communications twisting's to other management angles particularly the management. It becomes basic in this way for administrators, everything being equal, to 
comprehend the elements of corporate communications to businesses and how circumstance can be made to empower communications experts work to make the required effect.

Cornelissen (2011) notes that corporate communication involves both theory and practice which involves consolidating the particular and localized information that emerges from the intelligent reflection and applied exploration of experts practically speaking with scholastic examination that is by and large more reasonable and worldwide in standpoint which broadens our general information base of the corporate communications field. He accepts that a nearby connection among theory and practice will upgrade our general information and understanding just as advance the everyday act of communications experts.

Comelissen (2011) maintains that corporate communication as management function concentrations on organizational constructions, rules, schedules and compelling techniques that really work with the way toward settling on choice and execution concerning corporate communications. These he notes are the thought of the numerous communications professionals working across all spaces of inward and outer communications that should be composed in their work so an unmistakable, strong and predictable picture of the organization is projected to all of its stakeholders.

Pickiton citing Van Riel (1995 p3) remarks that 'practically speaking, the huge variety of inward communication "sources" can prompt divided, once in a while even conflicting, outer signs of the company overall. It along these lines turns out to be clear why it is feasible to notice a propensity to take a stab at expanded shared intelligibility between all types of inner and outer communication.' Integration must be operationalized and to do as such include the development of working relationships with bunches that may, previously, have been adversarial towards one another.

Burke (1999 p81) reveals that the community assessment, or as it is now and again called by essential planners, the outer assessment, is comparative in numerous regards to the company assessment. The goal is to gather information for creating techniques, programs, arrangements, and methodology that will situate the company well in the community; as such, to upgrade the reputation of the company as a neighbor of decision and, if the company decides to do as such, add to its upper hand. Burke additionally distinguished four sorts of genuine information that ought to be assembled in leading a community assessment to include: One is community data, the second is information on needs in the community, the third is information on the nature of the community's social and instructive resources, and the fourth is information on the community contribution programs of different organizations.

Grunig (1992) says organizations are viable when they accomplish their goals. Notwithstanding, goals should be fitting for the organization's current circumstance, or key constituencies (stakeholders and publics) inside that climate will compel the autonomy of the organization to meet its goals and accomplish its main goal. The highlights of every community bunch, the manners in which they impact organizations or are affected by them, assessment of their assumptions and the decision of fitting association management techniques, are on the whole elements to be investigated in each specific setting of each organization (Berman, Wicks, Kotha and Jones, 1999). Subsequently firms must be in touch with their stakeholders, perhaps fostering in a public relations capacity.

Argenti, , Howell, and Beck (2005) defines communication techniques as arranged activities in regards to communication about a specific issue, occasions identified with the fruitful execution of organizational goals, show of the organizational nature to the gatherings of stakeholders with which the organization keeps up with relationships. Communication techniques are straightforwardly connected to corporate procedures. Argenti et al, (2005) states further that fruitful corporate strategy should be touchy likewise to changes happening in the business climate and should be proactive. As per them, in developing communication methodologies it is important to consider the accompanying central matters:

1. The present status of the organization and its serious situation by setting up a SWOT investigation and execution of a communications review.

2. Communication with key stakeholders of the company through the exchange of predictable messages through different ably chose communication channels.

3. Developing a dream for the future wanted condition of the organization

4. Inspiration of stakeholders' co-interest in acknowledgment.

5. Defining attainable goals/SMART model/and making the proper strategies to accomplish them.

Fombrun and Shanley (1990) notes that corporate image resembles a mirror: it mirrors the personality of the organization. Having a great or negative image is resolved to some degree by the signs that an organization communicates about itself. These signs are understandings by stakeholders dependent on the company's activities and self-articulations. Fombrun and Shanley (1990) state further that the fulfillment of an enterprise's communication strategy is for the most part reliant upon how intently the communication strategy is associated with the strategy of the business completely. Notwithstanding kind plan and cautious planning of firm strategy, a business should have a strong corporate communication capacity to back its central goal and vision.

Christensen, Morsing, and Cheney (2008) back the contemporary communication model of dealing with the absolute corporate image, each division, across various crowds with a coordinated rational message. An essential communication stage with information stream of intentional 
informing consoles its constituencies while fortifying positive reputation.

Juholin (2009) says communication strategy assembles its core around the decisions, definitions and focuses on that the company connects with its stakeholders and climate in present and future conditions all together accomplish its general targets and strategy. Juholin, (2009) thinks further that communication strategy ought to consistently follow the company level strategy, so if there are changes in the strategy, communication ought to be audited and reexamined also. Henceforth, ceaseless development of communication can likewise be a decent essential apparatus. By following up and assessing the situation with the company communication, the minor hints of climate changes can be detected before.

Putnam (2000) Dunham, Freeman and Liedtka (2006) Harting, Harmeling and Venkataraman, (2006) Podnar and Jancic (2006) made classification of "community" with its particular highlights as follows: the spot of community affiliation; the country where a community creates; the gathering of individuals one completes some movement and shares interests with; the virtual community one partakes in, and so forth For them the importance of "community" appears to vary as indicated by one's specific perspective) thus, there are different meanings of networks, contingent upon which space of study they have a place with, and come from, for example theory, brain research, sociology, human studies, political theories, town planning, etc. Various classes of community permit organizations to feature conduct that they could receive in overseeing relationships with their stakeholders.

Anderson, (1997 p 34) opines that business achievement is grounded in a steady organization community. As per Anderson (1997) the highlights of every community bunch, the manners in which they impact organizations or are affected by them, assessment of their assumptions and the decision of proper connection management procedures, are on the whole elements to be broke down in each specific setting of each organization

\section{Theoretical Framework}

This study is anchored on two theories which are stakeholder's theory and corporate community theory

\section{Stakeholder Theory}

Stakeholder approach to strategy came up during the 1980. One point of convergence in this development was the distribution of Richard Edward Freeman. He is by and large credited with promoting the partner idea. The title of the work is-Strategic Management and just the caption is A Stakeholder Approach and turned out in 1984. Freeman (1984) characterizes conventional stakeholder as "any gathering or person who can influence or is influenced by the accomplishment of the organization's goals." The idea is about what the organization ought to be and how it ought to be conceptualized. Freeman (1984) offers an administrative and viable degree and doesn't actually establish a theory however comprised a base for the development of the stakeholder theory which has been generally evolved since the 1980's.

Friedman (2004) states that the actual organization ought to be considered as gathering of stakeholders and the motivation behind the organization ought to be to deal with their inclinations, necessities and perspectives. This partner management is believed to be satisfied by the chiefs of a firm. The supervisors ought to from one viewpoint deal with the enterprise to help its stakeholders to guarantee their privileges and the cooperation in dynamic and then again the management should go about as the investor's representative to guarantee the survival of the firm to shield the drawn out stakes of each gathering (Friedman 2004).

\section{The 'Corporate Community’ Theory}

In another economic theory of the firm proposed by Halal (2000 p10), the organization is seen as a socio-economic framework where stakeholders are perceived as accomplices who make esteem through shared critical thinking. Modern stakeholders work with supervisors to work on their own benefits while additionally upgrading corporate productivity. Business makes abundance by coordinating stakeholders into a useful a 'corporate community.' Halal (2000) brings up that this is done to give an upper hand not to be socially capable. As per Halel, corporate community along these lines includes commonsense, two-way working relationships where each group receives benefits in line with the contribution it makes.

\section{METHODOLOGY}

A survey research design was adopted for this study. Mixed method using interview and questionnaire was used for the study. The interview was used to elicit responses from the company's corporate communication department staff and the 6 members of project advisory committee while the questionnaire was used to get answers from the host communities.

\section{Population of the Study}

The population of this study is 74,240 . This figure is the sum of the respective populations of the six host communities of Indorama Elem Petrochemical Limited, namely, Aleto, Akpajo, Agbonchia, Njuru/Akpakpan, Okerewa and Elelenwo. The respective populations are derived from both official figures of National Population Commission (NPC) and Google Earth estimate figures of the Danish global population statistical service, City Population. Goggle Earth capture estimate by City Population (www.citypopulation.de) puts the projected population of the six host communities of IEPL as follows: Aleto 12,445; Akpajo 13,145; ,Abonchia 11,500; Njuru/Akpakpan 10,950; Okerewa 9,350; Elelenwo 16,850. Accordingly, the sum total of populations of the 6 host communities is 74,240 . The population of this study therefore is 74,240 . 


\section{Sample Size and Sampling Technique}

Two samples were taken for the study: one sample for quantitative data and another sample for qualitative data. For the quantitative data, a sample of 382 was arrived at, and for the qualitative data, a sample size of 9 was used.

For the quantitative data, the sample size was determined using Krejcie \& Morgan formula table for sample size. Hence at a population of 74,240 the formula produced a sample size of 382. However, for the qualitative data, purposive sampling technique was used to select the sample. The 3 staff of the Corporate Communication Department of Indorama Eleme Petrochemical limited and the 6 Project Advisory Committee (PAC) members of host communities represented the sample size for the interview.

This study adopted questionnaire and interview as data gathering instruments. The questionnaire was structured into A and B. section. A elicited the demographic elements of respondents while $\mathrm{B}$ focused on psychographic. 7 open ended questions were structured to answer the research question with four points Likert scale which determined the extent respondents agreed or disagreed. In qualitative method, information was collected by means of words and narratives.

\section{DATA PRESENTATION DISCUSSION AND FINDINGS}

\section{Analysis of Data from Interview}

\section{Question1. Corporate Communication Strategy of Indorama} Eleme Petro-Chemical Ltd.

The head of corporate communications who is the only participants said the company's Corporate Communications strategy is "constant engagement of stakeholder" which host community is a part

The company adopted the following technique of the communication strategies as outline by the head of corporate communication:

1. The technique using 'IMPACT Magazine'

2. The technique using using Indorama Eleme Petrochemical Limited website:

3. Another technique using of IEPL is telephone Communication

4. The Company also uses face-to-face communication strategy technique.

5. Business communication technique.

6. The in the same vain the company adopts Mass Media communications technique.

7. Interview technique with Chief Executive Officer or Managing director of Indorama Eleme Petrochemicals.

8. Notice Boards, Internal Memos and Circulars are also adopted as one of the organization's corporate Communications strategies.
Question 2: The extent corporate communication strategy of Indorama Eleme Petro-Chemical Ltd engenders sustainable community relations?

Areas corporate communication strategy of the company engenders sustainable community relations include the following:

1. Memorandum of Underrating (MOU) using community relations programme and community development projects

2. Project Advisory Committee (PAC).

3. $7.5 \%$ equity of the communities.

4. Regular Town Hall Meetings

Question 3: The extent host communities of Indorama Eleme Petro-Chemical Ltd appreciate the company's corporate communication strategy?

As result of constant engagement of the host communities and the positive community relations policies of the company effectively communicated through the company's corporate communications strategy the communities utilizes those channels of communication made available by the corporate communication department effectively.

1. In the IMPACT Magazine, two pages are devoted to "COMMUNITY IMPACT" which features the company community development projects. The Magazine is well distributed among community stakeholders including the traditional rulers, chiefs, community leaders, youth groups, women groups etc.

2. The Face-to-Face communication strategy is also effectively used especially when there is need to address, talk or dialogue with a host community. This assist the company to clear misconceptions or issues that is capable of breeding misunderstanding or crisis.

3. Telephone Communication strategy is as well used to engender sustainable community relations. It is effectively utilized to pass messages to host community representative especially the Project Advisory Committee.

4. Mass Media strategy which involves Newspapers, Radio and Television are effectively utilised to engender sustainable community relations. For instance Press Releases or statements are issued and News carried to both inform the communities on policies of the company.

Question 4: The challenges faced by Indorama Eleme PetroChemical Ltd in the application of corporate communication strategy of the organisation?

According to the corporate communications manager of the company, they have no challenges projecting constant stakeholder's engagements which is the communication 
strategy, because there is great relationship existing between the company and the host communities based on the reasons identified above.

The relative peace that reigns between the company and the host communities is as result of the robust engagement of the host communities and the positive community relations policies of the company effectively communicated through the company's corporate communications strategy. According to the head of corporate communications manager of the company, there would have been negative effect on host community relations as a result of non-communication or lack of communication.

\section{Analysis of Data from Questionnaire}

The field research is presented and analysed here using the data from questionnaire. It describes the figures and symbols to make meaning as well as discuss the findings. Data are presented in frequency table, percentage and weighted mean scores.

Table 1: Showing the proportionate distribution of the questionnaire

\begin{tabular}{|c|c|c|c|}
\hline Community & Population & Percentage & $\begin{array}{c}\text { No of } \\
\text { Questionnaire }\end{array}$ \\
\hline Aleto & 12,445 & 16.76 & 65 \\
\hline Akpajo & 13,145 & 17.70 & 68 \\
\hline Agbonchia & 11,500 & 15.49 & 59 \\
\hline Njuru/Akpakpan & 10,950 & 14.74 & 56 \\
\hline Okerewa & 9,350 & 12.59 & 48 \\
\hline Elelenwo & 16,850 & 22.69 & 86 \\
\hline Total & 74,240 & 100.00 & 382 \\
\hline
\end{tabular}

Analysis of Demographic Data

Table 2: Questionnaire Distribution and Rate of Respondents

\begin{tabular}{|c|c|c|}
\hline Category & Frequency & Percentages \\
\hline $\begin{array}{c}\text { Distributed } \\
\text { Questionnaire }\end{array}$ & 382 & $100 \%$ \\
\hline Retrieved Questionnaire & 371 & $97.12 \%$ \\
\hline Usable Copies & 367 & $96.07 \%$ \\
\hline
\end{tabular}

Total number of questionnaire copies distributed to six host communities of Indorama Eleme Petrochemicals Limited was 382. The copies returned were 371 which include the 4 invalid ones. Hence the number of copies valid and unable was 367. The percentage of retrieved questionnaire which were usable is $96.07 \%$

Table 3: Age Distribution of Respondents

\begin{tabular}{|c|c|c|}
\hline Age & Frequency & Percentages \\
\hline $15-18$ & 73 & $19.89 \%$ \\
\hline $19-25$ & 98 & $26.70 \%$ \\
\hline $26-30$ & 94 & 25.61 \\
\hline $30-$ Above & 102 & $27.79 \%$ \\
\hline Total & 367 & $100 \%$ \\
\hline
\end{tabular}

Table 4: Frequency Distribution of Respondents' Gender

\begin{tabular}{|c|c|c|}
\hline Gender & Frequency & Percentages \\
\hline Female & 163 & $44.41 \%$ \\
\hline Male & 204 & $55.59 \%$ \\
\hline Total & 367 & $100.00 \%$ \\
\hline
\end{tabular}

Table 5: Frequency Distribution of Educational Level of Respondent's

\begin{tabular}{|c|c|c|}
\hline Educational & Frequency & Percentages \\
\hline Primary School & 117 & $31.88 \%$ \\
\hline Secondary School & 152 & $41.42 \%$ \\
\hline Tertiary School & 98 & $26.70 \%$ \\
\hline Total & 367 & $100 \%$ \\
\hline
\end{tabular}

\section{Analysis of Psychographic}

The analysis of this section shall focus on the psychographics of respondents as contained in the questionnaire.

Table 6: Respondents' thoughts on effective communication channel with IEPL

\begin{tabular}{|c|c|c|c|c|}
\hline Response & Frequency & WS & WMS & Decision \\
\hline Strongly Agree & 195 & 780 & & \\
\hline Agree & 152 & 456 & & \\
\hline Disagree & 39 & 78 & & \\
\hline $\begin{array}{c}\text { Strongly } \\
\text { Disagree }\end{array}$ & 19 & 19 & & \\
\hline Total & 367 & 1,333 & 3.63 & Accepted \\
\hline
\end{tabular}

Respondents hold the opinion that channels of communication between IEPL and host communities are effective

Table 7: Respondent thoughts on company communicating Development Programmes and Projects

\begin{tabular}{|c|c|c|c|c|}
\hline Response & Frequency & WS & WMS & Decision \\
\hline $\begin{array}{c}\text { Strongly } \\
\text { Agree }\end{array}$ & 199 & 796 & & \\
\hline Agree & 117 & 351 & & \\
\hline Disagree & 41 & 82 & & \\
\hline $\begin{array}{c}\text { Strongly } \\
\text { Disagree }\end{array}$ & 10 & 10 & & \\
\hline Total & 367 & 1,239 & 3.38 & Accepted \\
\hline
\end{tabular}

Data shows that Respondents were of the opinion that the company communicates its development programmes and projects to communities.

Table 8: Respondents' thoughts on cordial relationship with IEPL.

\begin{tabular}{|c|c|c|c|c|}
\hline Response & Frequency & WS & WMS & Decision \\
\hline $\begin{array}{c}\text { Strongly } \\
\text { Agree }\end{array}$ & 201 & 804 & & \\
\hline Agree & 115 & 345 & & \\
\hline Disagree & 40 & 80 & & \\
\hline $\begin{array}{c}\text { Strongly } \\
\text { Disagree }\end{array}$ & 11 & 11 & & \\
\hline Total & 367 & 1,240 & 3.37 & Accepted \\
\hline
\end{tabular}


Data indicates that Respondents opinions are favourable to the cordial relationship between the company and host communities.

Table 9: Respondents' on Sustainable Community Relations Initiatives.

\begin{tabular}{|c|c|c|c|c|}
\hline Response & Frequency & WS & WMS & Decision \\
\hline $\begin{array}{c}\text { Strongly } \\
\text { Agree }\end{array}$ & 191 & 764 & & \\
\hline Agree & 93 & 279 & & \\
\hline Disagree & 49 & 98 & & \\
\hline $\begin{array}{c}\text { Strongly } \\
\text { Disagree }\end{array}$ & 34 & 34 & & \\
\hline Total & 367 & 1,175 & 3.20 & Accepted \\
\hline
\end{tabular}

Respondents' were of the opinion that there is a sustainable community relations initiative.

Table 10: Respondents' on receiving benefits from community development initiatives IEPL

\begin{tabular}{|c|c|c|c|c|}
\hline Response & Frequency & WS & WMS & Decision \\
\hline $\begin{array}{c}\text { Strongly } \\
\text { Agree }\end{array}$ & 204 & 816 & & \\
\hline Agree & 131 & 393 & & \\
\hline Disagree & 12 & 24 & & \\
\hline $\begin{array}{c}\text { Strongly } \\
\text { Disagree }\end{array}$ & 20 & 20 & & \\
\hline Total & 367 & 1,253 & 3.41 & Accepted \\
\hline
\end{tabular}

Respondents were of the opinion that their communities have benefited from development initiatives of the company.

Table 11: Respondents' on communication enhancing community relationship with company

\begin{tabular}{|c|c|c|c|c|}
\hline Response & Frequency & WS & WMS & Decision \\
\hline $\begin{array}{c}\text { Strongly } \\
\text { Agree }\end{array}$ & 121 & 484 & & \\
\hline Agree & 196 & 588 & & \\
\hline Disagree & 14 & 28 & & \\
\hline $\begin{array}{c}\text { Strongly } \\
\text { Disagree }\end{array}$ & 36 & 36 & & \\
\hline Total & 367 & 1,136 & 3.10 & Accepted \\
\hline
\end{tabular}

Respondents accepted that communication with community enhanced relationship with company.

Table 12: Respondents' on Challenges in Implementation of community relation with Programmes

\begin{tabular}{|c|c|c|c|c|}
\hline Response & Frequency & WS & WMS & Decision \\
\hline Strongly Agree & 106 & 424 & & \\
\hline Agree & 101 & 303 & & \\
\hline Disagree & 75 & 150 & & \\
\hline $\begin{array}{c}\text { Strongly } \\
\text { Disagree }\end{array}$ & 85 & 85 & & \\
\hline Total & 367 & 962 & 2.62 & Accepted \\
\hline
\end{tabular}

Respondents were of the opinion that there are challenges in the implementation of Community relations programmes.

\section{DISCUSSION OF FINDINGS}

The goal of this study was to get a pulse of the corporate communication strategies of Indorama Eleme Petrochemical Limited and how it engenders sustainable host community relations. The study yielded results and contributes to the body of literature in corporate communication and sustainable community relations. The results have proved that the communication strategies of Indorama Eleme Petrochemical Limited to a large extent is responsible for the mutual understanding that exist between the company and host communities and this has resulted in establishing development programmes and projects that are sustainable.

The findings of this study are explained by stakeholder theory and the results were consistent with the literature in many ways. Corporate communication strategies of the company end up being a significant contributory factor that upgraded sustainable community relations and guaranteed shared arrangement and harmony that as of now exist between the company and host networks. This is on the grounds that corporate communication systems of the company improve community relations commitment approaches of the company. This discovering plays into Van Riel position in his book on corporate communications as referred to by Comelissen (2004) which recommends that corporate communications is 'an instrument of management through which all deliberately utilized types of interior and outer communications are fit as successfully and efficiently as could really be expected', with the general goal of making 'a good reason for relationships with bunches whereupon the company is reliant.'

The argument of Argenti, Howell, and Beck (2005) which depicts communication techniques as arranged activities in regards to communication about a specific issue, occasions, identified with the fruitful execution of organizational goals, show of the organizational nature to the gatherings of stakeholders with which the organization keeps up with relationships typifies the corporate communication strategies of Indorama Eleme Petrochemical Limited as outlined in the finding which suggest that the communication strategies are effectively applied in ensuring sustainable host community relations. Hence the robust corporate communication strategies of the company are to great extent responsible for the peace that currently exists between the company and host communities. This therefore confirmed and satisfies the curiosity raised in the problem of this study which wondered why there is relative peace between Indorama Eleme Petrochemical Limited and host communities even when other companies in the area are in loggerhead with their host communities.

\section{SUMMARY AND CONCLUSION}

If the participants experiences and respondents opinion are indicative of a larger phenomenon, it could be possible that we are seeing a growth in this area of corporate communication strategies and sustainable community relations. 
While this is not an exhaustive study of corporate communication and sustainable community relations, it is a first step toward better understanding these concepts and bridging the gap between academic recording and industry knowledge on these issues. Through analysis of interview and questionnaire data, this dissertation showed corporate communication and community relations to be key factors in every organizational success.

It also opened the door for discussion on how operating strategically, utilization of effective corporate communication practices and building sustainable community relations can best be managed and harmonized for stakeholders' management and organizational growth.

In this study, the company's corporate communication strategies are applied effectively in handling host community relations. This is made manifest in the Memorandum of Understanding (MOU), activities of Project Advisory Committee (PAC), $7.5 \%$ equity of the communities and Regular Town Hall Meetings. These initiatives of the company, though unique in its conception, the one which seem to be most outstanding is the $7.5 \%$ equity of the communities in the company.

This to the researcher is the icing in the cake, in that Indorama seem to be one of its kinds that adopted such strategic move where the host communities see themselves as part owners of the organization. Therefore anything that will disrupt the operations or growth of the company affect their economic life to a large extent hence they would prefer better relationship which can be built through better communication strategies than any crisis.

It our view therefore, government at all levels should adopt and implement the Indorama Eleme Petrochemical Limited model of corporate communication strategies and sustainable community relations to ensure peaceful and mutual understanding between host communities and companies operating in the in Rivers State and Nigeria in general.

There is also need for companies in Rivers State to adopt a proactive communication strategies and sustainable community relations especially in regular review and renewal of Memorandum of Understanding (MOU) between organizations and host communities.
The need for further studies in the topic is also crucial especially in applying a different methodology.

\section{REFERENCES}

[1] Argenti, P., Howell, R., \& Beck, K. (2005). The strategic communication imperative. MIT Sloan management review, Spring. 46(3), 4-9.

[2] Anderson, C. (1997). Values-based management, Academy of Management Executive, 11(4), 25-46.

[3] Burke, E. M. (1999). Corporate community relation: The principle of the neighbour choice. Westport, London. Greenwood publishing group.

[4] Christensen, L., Morsing, M., \& Cheney, G. (2008). Corporate communications: convention, complexity, and critique. Journal of Mass Media Ethics. Communication \& mass media complete. doi: 10.1080/0890 0520902782953.

[5] City Population statistics, map and charts retrieved from https//www. citypopulation.de/php?/Nigeria-admin1id=NGA033

[6] Cornelissen, J. (2011). Corporate communication. A guide to theory and practice. Thousand Oaks: SAGE Publications.

[7] Fombrun, C. J., \& Shanley, M. (1990). What's in a name? Reputation building and corporate strategy. Academy of Management Journal, 33(2), 233-258.

[8] Freeman R. E. (1984). Strategic management: A stakeholder approach. Pitman Publishing: Boston.

[9] Freeman, R. E. (2004). A Stakeholder theory of modern corporations, ethical theory and business, $7 \mathrm{Ed}$.

[10] Grunig J. E. (1992). Excellence in public relations and communication management, Lawrence Erlbaum Associates: Hillsdale, N. J.

[11] Halal, W.E. (2000). Corporate Community: A Theory of the firm uniting profitability and responsibility. Strategic Leadership, $28(2), 1-11$

[12] Harting T. R., Harmeling, S. S., \& Venkataraman, S. (2006). Innovative stakeholder relations: When "Ethics Pays" (And When It Doesn't). Business ethics quarterly, 16(1), 6-9.

[13] Indorama- Nigeria Impact (2007, April-June)

[14] Indorama- Nigeria Impact (2008, January-March)

[15] Indorama- Nigeria Impact (2008, October - December)

[16] Indorama- Nigeria Impact (2009, April -June)

[17] Indorama- Nigeria Impact (2009, September- December)

[18] Indorama- Nigeria Impact (2010, January- April)

[19] Juholin, E. (2009). Communicare - Viestintä strategiasta käytäntöön. 5th Edition. Infor Oy

[20] Krejce \& Morgan table for sample size retrieved from www.kenpro.org sample size determinant

[21] Podnar K., \& Jančič Z. (2006) Towards a categorization of stakeholder groups: an empirical verification of a three-level model, Journal of Marketing Communications 12(4), 297-308.

[22] Putnam R. D. (2000) Bowling Alone: The collapse and revival of American community, Simon and Schuster, New York

[23] Van Riel, C. B. (2000). Principles of corporate communication. London: Prentice-Hall. 